\title{
АЮДЯМ, СОВЕРШИВШИМ ПОПЫТКУ САМОУБИЙСТВА, НУЖНА ОСОБАЯ ПСИХОТЕРАПИЯ
}

\author{
K. Michel \\ Бернский университет, Университетская психиатрическая и психотерапевтическая больница, г. Берн, \\ Швейцария
}

\section{PEOPLE WHO ATTEMPT SUICIDE NEED A SPECIFIC THERAPY}

K. Michel

University of Bern, Switzerland

Информация об авторе:

Michel Konrad - врач-психиатр, почётный профессор (Researcher ID: AAO-5546-2020; ORCID iD: 0000-00030725-5383;). Место работы и должность: почётный профессор Бернского университета, Университетской психиатрической и психотерапевтической больницы. Адрес: 3008, Швейцария, г. Берн, Муртенштрассе, 21. Электронный адрес: konrad.michel@upd.unibe.ch

Information about the authors:

Michel Konrad - MD, Professor Emeritus, Psychiatrist (Researcher ID: AAO-5546-2020; ORCID iD: 0000-00030725-5383;). Affiliation: University of Bern, Switzerland. Work address: University Hospital of Psychiatry and Psychotherapy, Murtenstrasse 21, 3008 Bern, Switzerland. Email: konrad.michel@upd.unibe.ch Websites: http://www.konradmichel.ch/, https://assip.ch/

Попытка суицида - главный фактор риска для повторных попыток суицида и смерти вследствие самоубийства. Пока лишь немногие терапевтические программы успешно и эффективно снижают суицидальный риск людей после попытки. В статье утверждается, что традиционная медицинская модель суицидального поведения не помогает активной вовлечённости пациентов в лечение, и потому нам нужен иной подход к суицидальному пациенту. Наша исследовательская команда разработала и оценила новую, краткосрочную и весьма рентабельную терапевтическую программу (краткая программа интервенции после попытки самоубийства, ASSIP). В противоположность медицинской модели, которая понимает суицид как последствие психической болезни, модель ASSIP основана на понимании суицида как личного поступка, который можно внимательно изучить в сотрудничающем терапевтическом подходе. Подход с позиций теории поступка радикально центрирован на пациенте, он понимается как агент, деятель своего суицидального поступка. Подход поддерживает активную вовлечённость пациентов в терапию. Главный её элемент - собственный нарратив пациента, который помещает суицидальную попытку в биографический контекст. С помощью терапевта суицидальный кризис может быть понят, объяснён и переосмыслен. ASSIP была оценена в рандомизированном контролируемом исследовании с 120 участниками. После 24 месяцев врачебного наблюдения экспериментальная группа имела сниженный на 80\% показатель повторных суицидальных попыток. Статья объясняет теоретические обоснования и развитие ASSIP, а также представляет обзор сессий ASSIP и обсуждение лечебных факторов терапевтического процесса.

Ключевые слова: попытка суицида, превенция суицидов, психотерапия, терапевтический альянс, рандомизированное контролируемое исследование

1. Введение.

Статья предлагает обзор новой краткосрочной терапевтической программы для пациентов, которые совершают попытку самоубийства, краткой программы интервенции после попытки самоубийства (Attempted Suicide Short Intervention Program, ASSIP). Лечебная модель ASSIP возникла из наблюдения, что между медиками и суицидальными пациентами наблюдается серьёзное нарушение коммуникации: собственные представления пациентов о суициде и представления
1. Introduction.

This article will give an overview of a brief and novel therapy program for patients who attempt suicide, the Attempted Suicide Short Intervention Program (ASSIP). The ASSIP treatment model originated from the insight that there are serious communication problems between suicidal patients and health professionals: The patients' own concepts of suicide and the concepts of professional helpers do not match. Yet, a meaningful therapeu- 
профессионалов не сходятся. Однако осмысленная терапевтическая беседа требует двух участников общения, которые имеют точки соприкосновения. Медицинские работники и суицидальные пациенты не понимают друг друга, говорят на разных языках: это настоящий синдром Вавилонской башни.

ASSIP основана на представлении о суициде как о поступке в противовес медицинской модели, в которой суицид рассматривается как симптом психиатрического расстройства. В теории поступка предполагается, что действия человека определяются системами целеполагания высшего порядка - проектами и жизненными целями. В модели теории поступка пациенты рассматриваются как агенты, авторы своих поступков, у которых есть свои личные причины для суицидального поведения. Терапия концептуализируется как пациент-ориентированный и сотрудничающий процесс, нацеленный на достижение общего, разделяемого обеими сторонами понимания суицидального кризиса пациента. ASSIP - это краткосрочная терапия из трёх сессий на основе руководства, разработанная для максимизации вовлечённости пациента в лечение и налаживание терапевтического альянса. Эта новая терапевтическая модель была разработана за последние 25 лет в Университетской психиатрической больнице г. Берна в Швейцарии. Эффективность ASSIP была проверена в рандомизированном контролируемом исследовании, опубликованном в 2016 году, и показала снижение риска повторных суицидальных попыток на $80 \%$ за 24 месяца. Сейчас проводится несколько повторных исследований, и команды в Европе, США и Азии успешно используют ASSIP в клинической практике.

\section{2. Недостатки медицинской модели.}

Главная проблема реабилитации пациентов, которые попадают в систему здравоохранения после попытки самоубийства, заключается в том, что примерно $50 \%$ таких пациентов не приходят на приём к врачу или преждевременно отказываются от лечения [1-4]. На это есть несколько причин. Одна из них: после получения скорой медицинской помощи в стационаре, допустим, после самоотравления, многие пациенты желают вернуться к обычной жизни, избегая любых напоминаний о суицидальном кризисе. Вторая причина: большинство людей, когда вспоминают о суицидальном кризисе, описывают диссоциативные симптомы суицидального поведения, например: «Я был в тот момент сам не свой» или «Я действовал будто на автопилоте». Таким людям трудно интегрировать акт самоповреждения в повседневную жизнь, а потому они избегают дальнейшего общения о нём. Третья причина: суицидальные люди редко ощущают, что медицинские работники их tic discourse needs two protagonists who can share a common ground. Health professionals and suicidal patients do not understand each other, they speak different languages - a true Tower of Babel syndrome.

ASSIP is based on the concept of suicide as an action, in contrast to the medical model, in which suicide is seen as a symptom of a psychiatric disorder. In action theory, a person's actions are understood as being determined by higher-order goal-oriented systems, such as projects and life-goals. In an action-theoretical therapy model, patients are seen as the agents of their actions, who have their personal reasons for their suicidal behaviour. Therapy is conceptualized as a patient-oriented and collaborative process aimed to reach a shared understanding of the patient's suicidal crisis. ASSIP is a brief, manual-based three-session therapy, devised to maximize treatment engagement and therapeutic alliance. This novel therapy model has been developed over the past 25 years at the University Hospital of Psychiatry in Bern, Switzerland. The effectiveness of ASSIP has been tested in a randomized controlled study published in 2016, showing an $80 \%$ reduction of the risk of suicide reattempts over 24 months follow-up. Several replication studies are currently on the way, and teams in Europe, USA, and Asia have been trained, and are successfully using ASSIP in clinical practice.

2. The problem with the medical model.

One of the main problems in the aftercare of patients who enter the medical system because of a suicide attempt is that some $50 \%$ of them do not attend a follow-up appointment, or drop out of treatment prematurely [1-4]. There are several reasons accounting for this. One of them is that after recovery from the intervention on the medical emergency unit, for instance after an overdose, many patients want to return back to normal life, avoiding further confrontation with their suicidal crises. A second reason is that most people, when in retrospect talking about it, describe dissociative symptoms in the moment of the suicidal behaviour, such as "I was not myself in this moment", or "I was acting like in an auto-pilot mode". These people find it difficult to integrate the act of self-harm into everyday life and therefore tend to avoid further confrontation. A third reason is that suicidal people rarely feel understood by health professionals, who usually conceptualize suicidal behaviour as a consequence of a psychiatric disorder. 
понимают, ведь обычно они осмысляют суицидальное поведение как последствие психиатрического расстройства. Медицинская подготовка снабжает медиков навыками распознавания патологии и диагностики соматических и психиатрических расстройств, но обычно не даёт им полезных моделей для понимания очень личного психологического опыта суицидального человека. Суицидальные пациенты постоянно сообщают, что медики их игнорируют, и воспринимают психиатрическую помощь как не полезную [5]. Любопытно, что одновременно некоторые пациенты замечают, что медсестры и социальные работники оказываются для них более полезны, чем доктора [6].

Следующая цитата взята из сообщения пациента о скоропомощном стационаре:

"Я очень злился, что они продолжали меня спрашивать, собираюсь ли я повторить попытку. Их не интересовали мои чувства. Жизнь не столь прямолинейна, и, если честно, я не мог сказать, повторю я попытку или нет. Однако мне было ясно, ито я не мог достаточно доверять этим врачам, чтобы откровенно беседовать с ними о себе».

Медицинская модель предполагает, что суицид является последствием психиатрического расстройства, чаще всего, депрессии. Проблема медицинской концептуализации суицидального поведения заключается в том, что она основана на «линейной модели», то есть, как и в моделях соматических заболеваний, она предполагает каузальную патологию и цепочку биологических и функциональных изменений, ведущих к специфическим симптомам, требующим специфического лечения. Связь между психической болезнью и суицидальным поведением основана на классических ретроспективных исследованиях, которые обнаружили типичные симптомы психиатрических диагнозов в более чем 90\% суицидов [7-9]. Однако эта модель суицидального поведения ошибочно воспринимает факторы риска в качестве причинных факторов. Хотя психиатрические диагнозы, без сомнения, - важные факторы риска суицида [10], такая модель показала весьма ограниченные способности снижать суицидальное поведение на популяционном уровне $[11,12]$. Несмотря на достижения фармакотерапии в лечении психиатрических расстройств, за последние десятилетия не наблюдается общего снижения уровня суицидов [13]. В традиционном медицинском подходе суицидальный человек - это пассивное существо, ведомое психиатрическим расстройством, а не человек с индивидуальной биографией, собственным внутренним миром, эмоциональной жизнью, жизненными целями и уязвимыми местами.

Очевидно, что нам нужно выйти за пределы медицинской модели, интегрировать другие аспекты суици-
Medical training equips health professionals with the skills to detect pathology and to diagnose somatic and psychiatric disorders, but it does not usually provide helpful models to understand the very personal psychological experience of the suicidal individual. Suicidal patients have repeatedly reported to feel ignored by health professionals, and to experience mental health care as unhelpful [5]. Interestingly, some of them said that nurses and social workers had been more helpful than doctors [6].

The following quote is from a patient on a crisis unit:

"I got very angry when they kept asking me if I would do it again. They were not interested in my feelings. Life is not such a matter-of-fact thing and, if I was honest, I couldn't say if I would do it again or not. What was clear to me was that I could not have enough trust in any of these doctors to really talk openly about myself."

The medical model assumes that suicide is a consequence of a psychiatric disorder, above all, depression. The problem with the medical conceptualization of suicidal behaviour is that it is based on a "linear model", that is, similar to somatic illness models, it assumes a causal pathology and a chain of biological and functional changes leading to specific symptoms, and finally to an illness-specific treatment. The association between mental illness and suicidal behavior is based on the classical retrospective studies which found the typical symptoms a psychiatric diagnosis in over $90 \%$ of suicides [7-9]. This model of suicidal behavior, however, mistakes risk factors for causal factors. Although psychiatric diagnoses are undoubtedly important risk factors for suicide [10], the illness-based model has shown a very limited potential to reduce suicidal behaviour on a population level $[11,12]$. Despite new developments in the pharmacotherapy of psychiatric disorders, there has been no general downwards trend in suicide rates over the last decades [13]. In the traditional medical approach, the suicidal person is a passive entity, driven by a psychiatric disorder, not a person with an individual biography, with her or his own inner world, with an emotional life, with life goals, and vulnerabilities.

Obviously, we need to look beyond the medical model, and integrate other aspects of suicidal behaviour $[14,15]$. In order to engage the suicidal person in a therapeutic process and treatment engagement, the therapist's aim must be to understand the 
дального поведения $[14,15]$. Чтобы вовлечь суицидального пациента в терапевтический процесс и лечение, психотерапевт должен быть способен понять внутренний, субъективный опыт собеседника. Психотерапевтические исследования показали, что обязательным условием вовлечённости в лечение является человекоцентрированная и смысловая модель лечения. В этом смысле, не депрессия - даже если она присутствует как фактор риска (и требует адекватного лечения!) - но сам человек является агентом суицидального поведения. Эффективные терапии фокусируются на индивидуальном, человеко-центрированном понимании суицида и суицидальных побуждений, например, когнитивно-поведенческая терапия (КПТ), диалектикоповеденческая терапия (ДПТ) и краткая программа интервенции после попытки суицида (ASSIP). Главные составляющие этих терапевтических моделей: (1) терапевтические отношения и раппорт (альянс); (2) активная вовлечённость пациентов в лечение, и (3) терапевтическое сотрудничество, направленное на достижение общей цели.

\section{3. Терапевтический альянс с суицидальным} пациентом.

Терапевтические отношения жизненно необходимы для эффективного лечения суицидальности. Лучшие методы, безошибочно применённые в нужное время, имеют ограниченную ценность (а то и вовсе никакой), если не существует адекватных терапевтических отношений и лечебного альянса [16].

Главный вызов в терапии суицидальных пациентов заключается в том, что терапевт должен быть аффективно созвучен суицидальному опыту пациента. Одна из главных трудностей для терапевта - способность проявить эмпатию к суицидальному желанию пациента и избежать попыток отговаривать пациента от них. Психотерапия с суицидальными пациентами может вызывать сильные реакции контрпереноса, включая сильные чувства гнева, безнадёжности и желания избежать общения. И все же искренняя попытка терапевта понять и принять субъективный опыт пациента, не пытаясь усомниться в нём, является определяющей для того, чтобы пациент смог справиться с душевной болью, даже если в суицидальном кризисе эта боль представляется невыносимой. А практика установления контакта (например, контактирование с пациентами, которые пропускают приём, по телефону или непосредственное их посещение на дому) увеличивает вовлечённость в лечение $[17,18]$.

Эмпатичный терапевт сообщает вербально и невербально, что переживания пациента, включая суицидальность, понятны ему в контексте текущего и прошлого опыта собеседника. Терапевт, который фунда- person's subjective inner experience. Psychotherapy research has shown that a prerequisite for treatment engagement is a person-centred and meaningful treatment model. In this view it is not depression even if present as risk factor (requiring adequate treatment!) - but the person who is the agent of the suicidal behaviour. Effective therapies focus on an individual, personcentered understanding of suicide and suicidal impulses, for instance, cognitive behavior therapies (CBT), Dialectical Behavior Therapy (DBT), and the Attempted Suicide Short Intervention Program (ASSIP). Key issues in these therapy models are (1) the therapeutic relationship and alliance, (2) active treatment engagement of the patients, and (3) the collaborative therapeutic work towards a common goal.

3. Therapeutic alliance with the suicidal patient.

The therapeutic relationship is vital to effective treatment of suicidality. The best techniques applied without error at precisely the right time are of limited, if any, value when an adequate therapeutic relationship and treatment alliance does not exist [16].

A major challenge in therapy with suicidal patients is that the therapist must be affectively attuned to the patient's suicidal experience. One of the most difficult aspects is the therapist's ability to show empathy for the patient's suicidal wish and to refrain from trying to talk the patient out of it. Psychotherapy with suicidal patients may evoke strong countertransference reactions, including intense feelings of anger, helplessness and the urge to withdraw. Yet the therapist's genuine effort to understand and accept the patient's subjective experience, without attempting to question it, is crucial to the patient's capacity to cope with mental pain, even if in the suicidal crisis the pain appears to be unbearable. Outreach elements (e.g., contacting patients who miss appointments, by telephone or home visits) will increase treatment engagement [17, 18].

The empathic therapist communicates verbally and non-verbally that the patient's affective experience, including suicidality, is understandable in the context of the patient's current and past experiences. The therapist who validates patients in a fundamental way demonstrates the belief that the patient has the capacity to learn to bear these feelings and to revert to non-suicidal goals [19]. The goal must be to enable the patient to cope with emotional crises and increase self- 
ментальным образом валидизирует (признаёт значимость опыта) пациента, обладает способностью научить переносить эти переживания и переключаться на несуицидальные цели [19]. Целью его должна стать помощь пациенту в совладании с эмоциональными кризисами и усиление его самоэффективности.

Хотя терапевтический альянс считается ключевым элементом терапии суицидальности, главные характеристики могут отличаться в зависимости от терапевтической модели. Например, в когнитивно-поведенческой терапии (КПТ) терапевт и пациент работают сообща, исследуя базовые убеждения и автоматические мысли пациента, чтобы сформировать индивидуальные цели (зачастую с помощью домашних заданий) [20]. Упор при этом делается на сотрудничестве и совместном исследовании «суицидальной системы убеждений» человека, которая включает триггеры, физические симптомы и связанное с суицидом поведение [21]. Терапевт - это активный и вовлечённый эксперт, который фокусируется на управлении симптомами (разрешении кризисов), построении навыков и личностном развитии [16]. Сотрудничающий эмпиризм понимается как способ сообщения эмпатии и, одновременно, веры в пациента [22]. Некоторые авторы рекомендуют использовать терапевтический контракт, в который обычно входит согласие пациента посещать сессии и участвовать в них, работать на достижение лечебных целей, выполнять домашние задания и активно участвовать в других элементах лечения, чтобы лучше справляться с суицидальными кризисами. M.D. Rudd и коллеги [23] определили общие элементы эффективного лечения, которые они вычленили из обзоров доступных рандомизированных клинических исследований лечения суицидальности. Один из таких элементов - обеспечение пациентов простыми и понятными моделями их суицидальности. Второй элемент - зарождение надежды, которая, как предполагается, имеет позитивные последствия для мотивации, приверженности лечению и способствует общему согласию с курсом лечения (комплаентности).

В диалектико-поведенческой терапии (ДПТ) терапевтический альянс строится на активной вовлечённости терапевта в терапевтические отношения [24]. В ДПТ роль терапевта характеризуется, с одной стороны, принятием внутреннего опыта пациента в данный момент, а с другой - подталкиванием пациента к смене дезадаптивных поведенческих схем [25]. ДПТ терапевт регулярно справляется о суицидальных побуждениях и действиях пациента. Привязанность пациента к терапевту рассматривается как привязанность к жизни в более широком смысле. Отношения с ДПТ терапевтом - это возможность «научиться лучше строить отноше- efficacy.

Although therapeutic alliance is considered a key element in the treatment of suicidality, the main characteristics may differ according to the therapeutic model. For instance, in cognitive behavioural therapy (CBT), therapist and patient work together, exploring the patients' core beliefs and automatic thoughts, in order to develop individual (often homework-based) goals [20]. The emphasis is on the collaborative exploration of a person's "suicidal belief system", which includes triggers, physical symptoms, and suicide-related behaviours [21]. The therapist is an active and engaged expert, focusing on symptom management (crisis resolution), skill building and personality development [16]. Collaborative empiricism is understood as a way of conveying empathy and, at the same time, competence to the patient [22]. Some authors recommend the use of a therapeutic contract, which usually includes the patient's agreement to attend and participate in the sessions, work toward achieving the treatment goals, complete homework assignments, and actively participate in other aspects of treatment in order to better manage their suicidal crises. M.D. Rudd et al. [23] identified common elements of effective treatments, distilled from a review of available randomised clinical trials targeting suicidality. One such element is providing patients with simple and understandable models for their suicidality. A second element is facilitating hope, which is expected to have positive implications in motivation, commitment and overall treatment compliance.

In Dialectical Behavioural Therapy (DBT) the therapeutic alliance is built on the therapist's active engagement in the therapeutic relationship [24]. In DBT the therapist's role is characterised by the tension between accepting the patient's inner experience at a given moment, and simultaneously pushing the patient towards changing maladaptive behavioural patterns [25]. The DBT therapist regularly enquires about suicidal urges and behaviour. The patient's attachment to the therapist is seen as an attachment to life in a broader sense. The relationship with the DBT therapist is an opportunity to "learn to do relationships better." Furthermore, the therapeutic relationship is a characteristic of the central dialectic of DBT (i.e., the ongoing expression of acceptance on the part of the therapist towards the patient) and is seen as a 
ния». Более того, терапевтические отношения характеризуют главную диалектику ДПТ (то есть постоянное выражение принятия пациента терапевтом) и рассматриваются как мощный двигатель изменений. Стратегии валидации (признания опыта пациента) необходимы для снижения эмоционального возбуждения, когда пациент оказывается в состоянии высокого стресса [26]. Поскольку эмоциональное возбуждение мешает когнитивному осмыслению и деятельности в целом, пациенту необходимо обрести эмоциональную регуляцию, чтобы осмыслять новую информацию и делать сотрудничество максимально эффективным.

В подходе CAMS (Collaborative Assessment and Management of Suicidality), коллаборативной оценке и управлении суицидальностью [27], альянс достигается через вовлечённость суицидального пациента в качестве активного участника оценивания своего суицидального риска и его сотрудничество как соавтора в антисуицидальном плане лечения. Взгляд пациента абсолютный «золотой стандарт» оценки его суицидального риска. Фокус «Формы суицидального статуса» (ФСС), в первую очередь, направлен на душевную боль и страдание пациента. Терапевт служит консультантом, тренером, соавтором в плане лечения. Эффективность CAMS показана D.A. Jobes и его коллегами [28].

4. Новый подход к суицидальному пациенту.

Самую очевидную грань суицида часто не замечают: суицид - это действие, поступок. Теория поступка рассматривает действия как поступки, которые выполняют деятели (агенты, авторы), то есть люди, которые ставят цели, замышляют планы, отслеживают и регулируют своё поведение, мысли и эмоции для достижения этих целей $[29,30]$. Теория целенаправленного поступка тесно связана с понятием саморегуляции [31]. Поступки связаны с системами целеполагания высшего порядка, которые формируются личностью и жизненной историей человека. В первом исследовании случая мы концептуализировали суицидальное поведение, используя модель теории поступка [32]. Мы показали, что суицид появляется как альтернативная цель по отношению к жизнеориентированным целям, когда в жизни человека возникает серьёзная угроза важным карьерным задачам или его идентичности. Последствием становится состояние эмоционального стресса с сильной душевной болью. В суицидальном кризисе долгосрочные перспективы теряют смысл, человек становится подвержен крайне краткосрочным целям, чья задача - положить конец невыносимому душевному состоянию. Суицид часто понимается как бегство от «Я» [33]. Смертеориентированные цели переживаются как эго-синтонные, и в этом для человека видится powerful agent for change. Validation strategies are crucial in reducing emotional arousal when a patient presents in a state of high distress [26]. Because emotional arousal interferes with cognitive processing and performance, the patient should be emotionally regulated to process new information in order to make the collaborative work maximally effective.

In CAMS, the Collaborative Assessment and Management of Suicidality [27] alliance is achieved by engaging the suicidal patient as an active participant in the assessment of the suicidal risk and by collaborating with the patient as a co-author of the suicide-specific treatment plan. The patient's view is the absolute "gold standard" for risk assessment. The focus of the Suicide Status Form (SSF) is primarily on the patient's psychological pain and suffering. The therapist serves as a consultant, coach, and co-author. The effectiveness of CAMS has been demonstrated by Jobes and colleagues [28].

4. A novel approach to the suicidal patient.

The most obvious facet of suicide is often overlooked: Suicide is an action. Action theory understands actions as being carried out by agents, that is by persons who are setting goals, making plans, monitoring and regulating their own behaviour, thoughts, and emotions in the pursuit of their goals $[29,30]$ The theory of goal-directed action is closely related to the concept of self-regulation [31]. Actions are related to higher-order goaldirected systems, which are shaped by a person's personality and biography. In a first case study we conceptualized suicidal behaviour using an action theoretical model [32]. We showed that suicide emerges as an alternative goal to life-oriented goals when in a person's life important life career issues or identity goals are seriously threatened. The consequence is a state of emotional stress with high psychological pain. In a suicidal crisis, long-term perspectives lose their meaning, the individual becomes subject to extreme short-term goals, aimed to put an end to this unbearable state of mind. Suicide has been conceptualised as escape from Self [33]. Death-oriented goals are experienced as ego-syntonic, as there is an inner logic for the person concerned.

An action conceptualization implies that the way people make sense of the actions of others, and the way people communicate their own actions is through story telling. The term narrative is used when the story is told to an 


\section{внутренняя логика.}

Концептуализация с позиции теории поступка подразумевает, что то, как люди осмысляют поступки других и сообщают о своих собственных поступках, происходит посредством рассказывания историй. Понятие «нарратив» используется, когда история рассказывается внимательному слушателю, придающему смысл событиям, чтобы объяснить логику конкретных действий. Связный автобиографический нарратив (рассказ) сам по себе создает чувство овладения ситуацией и усиливает эмоциональную стабильность [34]. Также это прототип разделяемого опыта, или совместного проекта, позволяющего пациенту генерировать альтернативные перспективы.

«Когда нам удаётся сформулировать правильную историю, и её выслушивает правильным образом правильный слушатель, мы оказываемся способны эффективнее справиться с опытом» [35].

Пациент и терапевт вместе фокусируются на разделяемом аспекте субъективности. Подлинно нарративный подход требует новых определений ролей пациента и терапевта. В нарративном подходе пациент «эксперт» своей суицидальной истории, а терапевт пребывает в «незнающей позиции», в то время как в психиатрической оценке психического состояния пациента терапевт оказывается экспертом. В «Руководстве для клиницистов», сформулированном Рабочей группой Эши [36] подчеркивается, что «главной целью должно быть вовлечение пациента в терапевтические отношения уже с первой оценочной беседы». В самом деле, несколько исследований показали, что ранний терапевтический альянс - ведущий фактор терапевтического результата $[37,38]$. Например, в краткосрочной терапии депрессии рано сформировавшиеся положительные терапевтические отношения предсказывали лучшую психосоциальную адаптацию пациентов спустя 18 месяцев [39].

Слушатель вступает в хронотоп, который конструирует рассказчик, помогает ему вести рассказ, а потому нарратив становится совместным творчеством в соответствии с правилами взаимодействия и разделяемого знания. Хорошая нарративная беседа учитывает все значимые факты, осмысляет опыт и не стигматизирует, и ощущается как достоверная и надёжная и клиницистом, и пациентом. Клиническим результатом нарративной беседы часто становится новая история с новым финалом. Особое влияние должно уделяться жизнеориентированным целям пациента, которые в суицидальном кризисе могут подвергаться экзистенциальным угрозам. Хотя в суицидальном кризисе восприятие настоящей ситуации и себя может быть окрашено подавленным настроением и мрачными размышлениями, attentive listener, giving meaning to events, in order to explain the logic of a specific action. A coherent autobiographical narrative in itself creates a sense of mastery and enhances emotional stability [34]. It is also the prototype of a shared experience, or joint project, allowing the patient to generate alternative perspectives.

"When we are able to formulate the right story, and it is heard in the right way by the right listener, we are able to deal more effectively with the experience" [35].

Patient and therapists thus jointly focus on a shared aspect of subjectivity. A truly narrative approach requires newly defined roles of the patient and the therapist: In the narrative the patient is the ,expert" of his or her suicide story, the therapist being in a ,not knowing position", while in the psychiatric assessment of the patient's mental state the therapist is the expert. The Guidelines for Clinicians formulated by the Aeschi Working Group [36] emphasize that ,the ultimate goal should be to engage the patient in a therapeutic relationship, even in a first assessment interview." Indeed, several studies suggested that the early therapeutic alliance is a major factor for therapy outcome [37, 38]. For instance, in a brief treatment of depression, an early positive therapeutic relationship predicted better adjustment and better adaptive capacities in an 18-months follow-up [39].

A listener enters into the temporal world the narrator constructs, helps in the telling, and thus narratives are jointly accomplished, according to shared knowledge and interaction rules. A good narrative interview encompasses all the relevant facts, makes sense of the experience, is non-stigmatising, and will be credible to both the clinician and the patient. The clinical outcome of a narrative discourse is often a new story with a new ending. Special attention should be placed on the patient's life-oriented goals, which in a suicidal crisis may be existentially threatened. Although in the suicidal crisis the perception of the present situation and the self may be coloured by depressed mood and cognitions, in our clinical experience individuals generally have an impressive narrative competence, provided that the interviewer is prepared to adopt an open, nonjudgmental and supporting attitude. Story telling needs a sensitive listener. If patients do not feel understood, they are likely to end the story prematurely.

In a clinical study based on single inter- 
в нашем клиническом опыте люди обычно обладают внушительной компетенцией рассказчиков, если слушатель готов занять открытую, не осуждающую и поддерживающую позицию. Рассказывание истории требует чуткого слушателя. Если пациент не чувствует себя понятым, он скорее всего оборвет историю преждевременно.

В клиническом исследовании единичных интервью людей после суицидальной попытки мы обнаружили, что оценка пациентами качества терапевтических отношений, которая учитывалась с помощью «Пенсильванского опросника помогающего альянса» [40], была значительно выше, когда в начальной фразе интервью собеседник применял нарративный подход [41] и использовал слова «рассказывать» («Пожалуйста, расскажите мне, как вы пришли к тому, что стали причинять себе вред?») или «история» («Я хотел бы услышать историю, которая привела вас к суицидальному кризису»). Вторым открытием стало, что оценка по опроснику была выше, когда в расшифровках интервью мы обнаруживали, что собеседники признавали важность биографических моментов, связанных с суицидальностью («Понимаете, мой страх потерять близкого человека идёт ещё из детства»).

После нарративной беседы мы предложили сессию, в которой пациентам показывали видеозапись этой беседы. Просмотр видеозаписи и методика самоконфронтации описана несколькими авторами [42-44]. На сессии с просмотром видеозаписи пациент и терапевт сидят бок о бок перед экраном и смотрят запись беседы. Они время от времени нажимают на паузу и пациента просят сообщить о мыслях, чувствах и ощущениях, которые у него возникают при просмотре беседы, а также справляются о дополнительной информации касательно суицидального нарратива. Цель просмотра видео - достичь эмоциональной дистанции и способствовать самонаблюдению и лучшему осознаванию себя пациентом. Просмотр видеозаписи - это мощная техника развития рефлексии и осознания эмоциональных и когнитивных механизмов, связанных с суицидальным поведением, как можно заметить на примере этого письма.

\section{Дорогой доктор,}

С тех пор как я пообщался с вами, я чувствую, будто ноша спала с моей души. Хотя неделю назад я пережил нечто, похожее на зарождение мыслей о самоубийстве, я действительно чувствую себя лучше, чем три недели назад, после попытки. С тех пор я больше обшался с друзьями и снова и снова пытался объяснить произошедшее. Я чувствую, ито беседа и, главное, просмотр видео после неё, дали мне очень много в смысле душевной проработки. Сегодня мне стало гораздо понятнее, сколь "глупа" такая попытка суииида, да и сам суииид. views with suicide attempters we found that patients' ratings of the quality of the therapeutic relationship in the Penn Helping Alliance Questionnaire HAQ [40] were significantly higher when, in the opening sentence of the interview, the interviewer used a narrative approach [41], using the words "tell" (e.g. "can you please tell me how you came to the point of harming yourself?") or "story" (e.g. "I would like to hear the story behind the suicidal crisis"). A second finding was that HAQ scores were higher when in the interview transcripts we found that interviewers acknowledged the importance of biographical issues related to suicidality ("You know, my fear of losing a close person goes right back to my childhood").

Following the narrative interview, we introduced a session, in which patients were confronted with the video-recorded interview. The video-playback and selfconfrontation technique has been described by several authors [42-44]. In the video playback session patient and therapist sit side by side in front of the screen watching the recorded interview. The video is paused from time to time and patients are invited to report on any thoughts, feelings and sensations they had watching the interview, as well as to provide additional information regarding the suicide narrative. The aim of the videoplayback is to achieve emotional distancing and fostering self-awareness and insight. The video playback is a powerful technique to foster reflection and insight into the emotional and cognitive mechanisms related to suicidal behaviour, as the following letter exemplifies.

\section{Dear doctor}

Since I have seen you I have been feeling unburdened. Although about a week ago I experienced again something like beginning thoughts about suicide, I do feel better than three weeks ago, after the suicide attempt. Since then I also talked more with friends, and I tried again and again to explain what happened. I feel that the interview, and above all, watching together the video afterwards, gave me very much in terms of working through. Today it is much more clear to me what a "silly" idea such a suicide attempt, or suicide itself, is.

Again, many thanks! With best regards, R.W.

Another patient said:

"You know, doctor, hearing my story again is shocking. I was not my usual self when I did this. This is real frightening. I never want to get into such a situation again." 
Ещё раз, большое спасибо! С наилучшими пожеланиями, Р.В.

Другой пациент писал:

"Знаете, доктор, я был шокирован, когда вновь услышал свою историю. Я был не в себе, когда делал это. Это очень пугает. Я не хочу никогда вновь попадать в такую ситуаиию".

В терминах теории поступка, метод просмотра видеозаписи - это совместная деятельность пациента и терапевта, направленная на общую цель: понять критические моменты суицидального процесса в контексте значимых биографических тем, чтобы определить факторы уязвимости и запуска процесса и сформировать стратегии выживания в будущих суицидальных кризисах. При просмотре видеозаписи и самоконфронтации пациент, уже изменившийся по сравнению с той сессией беседы, ставится в роль внешнего наблюдателя.

5. ASSIP: Краткая программа интервенции после попытки самоубийства

ASSIP - это программа лечения, основанная на описанной выше теории поступка как суицидального поведения. Она состоит из трёх 60-90 мин сессий, в идеальном случае в течение 3-4 недель. Четвёртая сессия может быть добавлена при необходимости.

Первая сессия.

Проводится нарративная беседа, в которой пациента просят рассказать свою личную историю, как он пришёл к желанию убить себя и как это воплощалось. Цель нарративной беседы: достичь - в биографическом контексте - пациент-центрированного понимания индивидуальных механизмов, ведущих к психологической боли и суицидальному поведению, и выявить особые факторы уязвимости и события - триггеры. Все беседы записываются на видео с письменного согласия пациента.

\section{Вторая сессия.}

Пациент и терапевт смотрят избранные моменты записи видео-интервью, сидя бок о бок. Так пациент помещается в позицию наблюдателя и смотрит запись суицидального нарратива от первой сессии. Терапевт помогает достичь подробной реконструкции перехода от опыта психологической боли и стресса к суицидальным действиям. Определяются автоматические мысли, эмоции, физиологические сдвиги и связанное с этим поведение. В конце сессии пациенту выдается психообразовательный буклет («Суицид - нерациональный поступок») в качестве домашнего задания: его нужно будет вернуть с личными комментариями на следующей сессии. Буклет призван установить разделяемую (терапевтом и пациентом) модель суицидального поведения, интегрируя теоретические понятия, такие как факторы суицидального риска, душевная боль, суици-
In action theoretical terms, the video playback technique is a joint action between patient and therapist, aimed at a common goal: To understand the critical points of the suicidal process in the context of relevant biographical issues, to identify vulnerability and trigger factors, and to develop strategies for survival in future suicidal crises. In the video-playback and self-confrontation, the patient, different to the narrative session, is put into the role of the outside observer.

5. ASSIP: The Attempted Suicide Short Intervention Program.

ASSIP is a treatment program based on an action-theoretical concept of suicidal behavior as described above. It is administered in three $60-90 \mathrm{~min}$ sessions, ideally within three to four weeks. A fourth session can be added if considered necessary.

First Session.

A narrative interview is conducted, in which patients are asked to tell their personal stories about how they had reached the point of wanting to kill themselves, and how they went about it. The aim of the narrative interview is to reach - in a biographical context - a patient-centred understanding of the individual mechanisms leading to psychological pain and suicidal behaviour, and to elicit specific vulnerability factors and trigger events. All interviews are video-recorded, with the patients' written consent.

\section{Second Session.}

The patient and therapist watch selected sequences of the video-recorded interview, sitting side-by-side. Thus, the patient is put into the observer's seat, watching the suicide narrative recorded in session one. The therapist helps to provide a detailed reconstruction of the transition from an experience of psychological pain and stress, to the suicidal action. Automatic thoughts, emotions, physiological changes, and related behaviour are identified. At the end of the session, two patients are given a psychoeducative handout ("Suicide is not a rational act") as a homework task, to be returned, with personal comments, at the next session. The handout aims to establish a shared model of suicidal behaviour, by integrating theoretical concepts such as suicide risk factors, psychological pain, and the suicidal mode, as well as basic neurobiological correlates of the suicidal mind. Following the second session, the therapist prepares a written draft of the case conceptualization. 
дальный модус поведения, а также базовые нейробиологические корреляты суицидальной психики. После второй сессии терапевт готовит письменный черновик концептуализации случая.

\section{Третья сессия.}

Обсуждается обратная связь от пациента в ответ на буклет. Черновик концептуализации случая совместно изучается и правится. Концептуализация случая формулирует личные потребности / жизненные цели, связанные с ними уязвимости и суицидальные триггеры, обеспечивая обоснование потребности сформулировать индивидуальные тревожные знаки и стратегии обеспечения безопасности для будущих суицидальных кризисов. Письменная концептуализация случая и личные стратегии безопасности распечатываются и выдаются пациенту, а дополнительная копия хранится у врача и других специалистов, участвующих в лечении. Долгосрочные цели, тревожные знаки и стратегии безопасности копируются на небольшом листочке, который сворачивается в формат визитки, и её тоже отдают пациенту. Пациента просят всегда носить с собой этот листочек и заглядывать в него в случае эмоционального кризиса.

\section{Письма.}

Пациентам шлют полустандартизированные письма в течение 24 месяцев, в первый год - каждые 3 месяца, а во второй - каждые полгода. В письмах пациентам напоминают о долгосрочном риске будущих суицидальных кризисов и о важности стратегий безопасности. Письма подписываются лично терапевтом ASSIP. Пациентов информируют, что они не обязаны отвечать на письма, но обратная связь о том, как у них идут дела, приветствуется. В случае, если пациенты отвечают (обычно по электронной почте), терапевт ASSIP учитывает это в следующем письме.

Обзор компонентов терапевтической программы ASSIP:

1) Нарративная беседа: установление сотрудничающих терапевтических отношений.

2) Просмотр видеозаписи и самоконфронтация: переосмысление нарратива путём дистанцирования и помещения пациента в роль внешнего наблюдателя.

3) Буклет / домашнее задание: форма сотрудничающего психообразования - люди узнают о суицидальном модусе поведения как это связано с функционированием мозга и прочее.

4) Лично и совместно разработанная концептуализация случая: помещение события в контекст, идентификация уязвимости и триггеров, то есть возможных будущих опасных ситуаций.

5) Персонализированное планирование безопасности: совместно разработанные стратегии безопасности,
Third Session.

The patients' written feedback, in response to the handout, is discussed. The draft of the case conceptualization is collaboratively revised. The case conceptualization formulates personal needs / life-goals, related vulnerabilities and suicide triggers, providing the rationale for the need to develop individual warning signs and safety strategies for future suicidal crises. The written case conceptualization and the personal safety strategies are printed and handed out to the patient, with additional copies for the health professionals involved in treatment. Long-term goals, warning signs, and safety strategies are copied to a credit-card sized folded leaflet and given to the patient. Patients are instructed to carry this leaflet on them at all times, and to consult it in the event of an emotional crisis.

\section{Letters.}

Participants are sent semi-standardized letters over a period of 24 months, 3-monthly in the first year, and 6-monthly in the second year. The letters remind participants of the long-term risk of future suicidal crises and the importance of the safety strategies. Letters are signed personally by the ASSIP therapists. Patients are informed that they do not have to respond to the letters, but that a feedback about how things are going would be welcome. In the cases where patients write back (usually via e-mail), the ASSIP therapist acknowledges this in the next letter.

Summary of the components of the ASSIP therapy program:

1) Narrative interviewing: Establishing a collaborative therapeutic relationship.

2) Video playback and self - confrontation: Reprocessing of the narrative by distancing and putting the patient into the role of the outside observer.

3) Handout / homework: A form of collaborative psychoeducation, people would learn about the suicidal mode, how this relates to brain function, etc.

4) Personal and jointly developed case conceptualization: Putting things into context; identification of vulnerability and triggers, that is, of possible future dangerous situations.

5) Personalized safety planning: Collaboratively developed safety strategies, supplemented with a pocket leaflet ("Leporel$10 ")$.

6) Regular letters: Outreach element, as continuation of the therapeutic relationship, and reminder of the safety measures. 
закреплённые памяткой («Лепорелло»).

6) Регулярные письма: контакт после выписки, продолжение терапевтических отношений и напоминание о мерах безопасности.

Для более подробного описания, см. сайт assip.ch и руководство по методу ASSIP [45].

6. Исследования эффективности.

На протяжении 24 месяцев 120 пациентов, обратившихся в медучреждение после попытки суицида, участвовали в исследовании [46]. Вместе с периодом последующего наблюдения всё исследование длилось 4 года. Пациентов случайным образом распределяли в контрольную (60 человек) или группу ASSIP (60 человек). Все пациенты имели одинаковые назначения, под чем подразумевалось психиатрическое стационарное лечение, краткосрочная кризисная терапия, амбулаторное лечение или вовсе никакого. Собиралась подробная информация о стандартном лечении при поступлении и в течение наблюдения, включая лекарственную терапию, количество дней госпитализации, количество амбулаторных встреч и т.д. ASSIP давался в три встречи-сессии в соответствии с руководством, в то время как у контрольной группы была лишь одна сессия оценки суицидального риска. Всех пациентов просили заполнять набор опросников каждые 6 месяцев.

Результаты:

Главным показателем эффективности было количество повторных суицидальных попыток в течение периода наблюдения. За 2 года в группе ASSIP было совершено 5 повторных попыток, а в контрольной - 41 попытка. В процентном соотношении количество участников, совершавших повторные попытки, составило $8,3 \%$ (5 человек) и 26,7\% (16 человек), соответственно. Анализ выживаемости показал, что в группе ASSIP риск совершения как минимум одной повторной попытки суицида снижался на $80 \%$. Кроме того, участники экспериментального лечения в период наблюдения проводили меньше дней на психиатрическом стационарном лечении. Мы также обнаружили, что группа ASSIP показала отрицательную корреляцию между оценкой качества терапевтических отношений с точки зрения пациента и суицидальными мыслями. То есть, чем более полезным пациенты считали терапевтические встречи (3 сессии), тем меньше суицидальных мыслей они испытывали в первый год наблюдения [47, 48].

Позже исследование Park из Лондонской школы экономики обнаружило превосходное соотношение эффективности и стоимости ASSIP. Вероятность, что ASSIP сократит затраты в течение 24 месяцев, была очень высока даже при низком уровне готовности пла-
For further details, see assip.ch and the ASSIP manual [45].

6. Effectiveness study.

Over a time-span of 24 months 120 patients referred after a suicide attempt participated in this study [46]. With a follow-up period of 2 years the study was running for altogether 4 years. The patients were randomly assigned either to the control group (60) or the ASSIP group (60). All patients had treatment as usual, which could mean anything between psychiatric inpatient treatment, shortterm crisis treatment, outpatient care, or no treatment at all. Detailed information on treatment as usual at referral to the study and during follow-up was collected, including medication, days of hospital treatment, number of outpatient sessions, etc. ASSIP was provided in three sessions, in adherence to the manual, while the control group had just one single suicide assessment session. All patients were asked to fill in a set of questionnaires every 6 months.

Results:

The primary outcome measure was the number of repeated suicide attempts during follow-up. At 24-months, a total of 5 repeat attempts were recorded in the ASSIP group, vs 41 in the control group. The rates of participants reattempting suicide at least once were $8.3 \%(\mathrm{n}=5)$ and $26.7 \%(\mathrm{n}=16)$, respectively. The survival analysis showed that in the ASSIP group the risk of participants making at least one repeat suicide attempt was reduced by $80 \%$. In addition, the ASSIP participants during follow-up spent significantly fewer days in psychiatric inpatient treatment. We also found that the ASSIP group showed an inverse correlation between the measures of the quality of the therapeutic relationship as rated by the study participants (HAQ) and suicidal ideation. That is, the more helpful the patients found the therapist in the three sessions, the fewer suicidal thoughts they indicated during the first-year follow-up [47, 48].

Later, a study by A. Park from the London School of Economy revealed an excellent cost-effectiveness of ASSIP. The probability that ASSIP was cost saving at 24 months was very high even at very low levels of willingness to pay. Most of the cost savings were driven by significantly lower costs for general hospital services and less use of inpatient care services in the ASSIP group [49].

7. What makes ASSIP effective? 
тить за терапию. Бо̀льшую часть экономии составляло сокращение затрат на госпитализацию в скоропомощной стационар и психиатрическое стационарное лечение пациентов из группы ASSIP [47].

7. Почему ASSIP эффективна?

Учитывая замечательную эффективность терапии, состоящей из 3 сессий, мы спросили себя, может ли новая модель лечения, разработанная в Берне, указать новое направление для лечения суицидальных людей. ASSIP представляет собой сочетание нескольких факторов, и трудно сказать, какой элемент особенно важен для объяснения её эффективности. Вот главные факторы терапевтического процесса, которые можно выделить в ASSIP.

I. Понимание суицида как поступка, а не симптома болезни. Ключ к лечению лежит в самом человеке. Пациент - эксперт своей истории, эта история и триггеры суицидального кризиса помещаются в центр беседы. Задача терапевта - вовлечь пациента в активное участие в терапевтическом процессе.

II. Терапевтический подход характеризуется такими концепциями как надёжная основа [50], нарративная беседа [51], совместная ментализация [51] и сотрудничающее психообразование [52].

III. Просмотр видеозаписи - это метод, который помогает пациенту посмотреть на свой суицидальный кризис с иной точки зрения, с активной помощью терапевта как соавтора.

IV. Буклет обеспечивает пациент - ориентированную модель суицида, вместе с домашним заданием, побуждающим пациента достичь собственного понимания и инсайта: в психотерапии используется термин «слияние моделей» - в противовес синдрому Вавилонской башни, описанной в начале статьи.

$\mathrm{V}$. Концептуализация случая обеспечивает пациента письменным обобщением разных элементов суицидального кризиса, включая описанные в истории его жизни потребности и уязвимости. Опять-таки, это опыт терапевтического сотрудничества, в котором пациент оказывается соавтором. Стратегии безопасности логически следуют из формулировки случая.

VI. «Лепорелло», памятка размером с визитку, напоминает пациенту о терапевтическом послании («Суицид - это поступок, но неподходящий поступок»). Памятка может рассматриваться как личный сувенир, поскольку терапевт в присутствии пациента берёт ножницы, вырезает памятку из большого листа, аккуратно складывает и передаёт пациенту.

VII. Регулярные письма, как уже было сказано ранее, имеют несколько функций. В ASSIP главной задачей, пожалуй, является «продолжение контакта» терапевтических отношений. Это главное отличие от «ис-
Considering the remarkable effect of a three-session therapy, we asked ourselves if the novel treatment model we had developed in Bern could possibly indicate new directions for the treatment of suicidal individuals. ASSIP is a package of several factors, and it is difficult to say which element was particularly important to explain its effectiveness. Here are the main therapy process factors which can be identified in ASSIP.

I. Understanding suicide as an action and not a symptom of illness. The key to treatment lies in the individual. The patient is the expert, the very individual background and trigger of the suicidal crisis is in the center. The therapist's task is to involve the patient as active participant in the therapy process.

II. A therapeutic approach that is characterized by such concepts as the secure base [50], narrative interviewing [51], joint mentalizing [52], and collaborative psychoeducation [53].

III. The video-playback as a technique that helps the patient to view the suicidal crisis from a different perspective, with the active help of the therapist as co-author.

IV. The handout providing a patientoriented model of suicide, together with the homework task activating the patient's own understanding and insight - a term used in psychotherapy research is "convergence of models" - in contrast to the Tower of Babel syndrome described above.

V. The case conceptualization providing patients with a written summary of the different elements of the suicidal crisis, including the biographical needs and vulnerabilities. Here again, this is a collaborative therapeutic experience, with the patient as co-author. The safety strategies follow logically from the case formulation

VI. The credit card-sized Leporello reminds the patient of the therapist's message (Suicide is an action but a wrong action). It may be seen as a personal token, because the therapist, in the patient's presence, takes the scissors, cutting the Leporello out from the printed paper, folding it carefully and handing it to the patient.

VII. The regular letters, as discussed earlier, may have several functions. In ASSIP, the main function is probably the "outreach continuation" of the therapeutic relationship. This is the main difference to the "caring letters studies" $[54,55]$, where the outreach element was not combined with a previous person-centred therapy.

ASSIP respects personal autonomy. 
следований писем заботы» $[54,55]$, в которых элемент контакта не объединяется с предшествующей человекоцентрированной терапией.

ASSIP уважает личную автономию. Люди принимают новое поведение, только когда оно несёт для них смысл. В соответствии с теорией самодетерминации, принятие новых целей и поведения требует внутренней мотивации, и это происходит, когда клиенты чувствуют, что терапевт слушает, ценит и понимает их [56]. ASSIP - единственная терапевтическая программа, которая посвящает всю сессию нарративу пациента. То есть пациент получает полную возможность выговориться. В течение сессий ASSIP применяет строго сотрудничающий подход, в котором терапевт не даёт советов и инструкций.

\section{8. Заключение.}

Главная проблема клинической превенции суицидов заключается в том, что большинство людей, склонных к суицидальному поведению, переживают свои суицидальные мысли и планы как эго-синтонные. Они не чувствуют, что им нужна медицинская или психиатрическая помощь. Медицинские работники, с другой стороны, склонны рассматривать суицид, в первую очередь, как последствие психиатрического расстройства, требующего лечения, часто психофармакологического. Психиатрические расстройства - это факторы риска, но не причина суицида. Вовлечённость в лечение требует общих точек соприкосновения, понимания, и это особенно важно для пациентов, контактирующих с медицинской системой после суицидальной попытки. Они представляют собой группу с наивысшим риском суицида и повторных попыток, и их можно вовлечь в лечение. Существует несколько поведенческих психологических терапий, которые используют сотрудничающий терапевтический подход. ASSIP, краткая программа интервенции после суицидальной попытки это краткосрочная терапия, состоящая из 3 сессий, которая использует новый терапевтический подход, основанный на понимании суицида как поступка, являющегося частью систем целеполагания высшего порядка. Рандомизированное исследование 120 пациентов обнаружило снижение повторных суицидальных попыток на $80 \%$ за 24 месяца. Высокая эффективность ASSIP в снижении суицидального поведения заставляет задуматься о том, что успех достигается именно благодаря подходу к суицидальному пациенту, основанному на представлении о суициде как о поступке, что следует учитывать в будущих проектах превенции суицидов.

Литература / References:

1. Fawcett J., Scheftner W.A., Fogg L. et al., Predictive factors of post-discharge follow-up care among adolescent suicide attempters. Acta Psychiatrica Scandinavica. 2001; 104: 31-36.
People adopt a new behavior only when it makes sense to them. According to SelfDetermination Theory adopting new goals and a new behavior requires intrinsic motivation, and this happens when clients feel listened to, valued, and understood by their therapist [56]. ASSIP is the only therapy program that allocates a full session to the patient's narrative. That is, the patient has the floor. Throughout the sessions ASSIP uses a strictly collaborative approach, in which the therapist holds back with advice and instructions.

8. Summary.

A major problem in clinical suicide prevention is that most people who are subject to suicidal behavior experience their suicide thoughts and plans as ego-syntonic. They do not feel that they need medical / psychiatric treatment. Medical health professionals on the other hand tend to see suicide primarily as a consequence of psychiatric disorders that need treatment, often psychopharmacological. Mental health disorders are risk factors, but not the cause of suicide. Treatment engagement requires a common basis of understanding, and this is particularly important for patients who come in contact with the medical system after a suicide attempt. They represent the population with the highest risk of suicide and repeated attempts, and they can be taken into treatment. There are several behavioral psychological treatments that use a collaborative therapeutic approach. The Attempted Suicide Short Intervention Program ASSIP, a brief three-session treatment, uses a novel therapeutic approach based on the concept of suicide as an action that is part of higher-order goal-oriented systems. A randomized study with 120 patients found an $80 \%$ reduction of suicide reattempts over 24 months.

The remarkable effectiveness of ASSIP in reducing suicidal behavior raises the question if an approach to the suicidal patient based on the concept of suicide as an action could be successful introduced in future suicide prevention projects.
2. Monti K., Cedereke M., Ojehagen A. Treatment attendance and suicidal behavior 1 month and 3 months after a suicide attempt: a comparison between two samples. Archives of Suicide Research. 2003; 7: 167-174. 
3. Möller H.J. Evaluation of aftercare strategies, in Suicidal Behaviour and Risk Factors, M.G. Ferrari, Bellini, P., Crepet, Editor. Monduzzi Editore: Bologna, 1990. P. 419-434.

4. Möller H.J. Efficiency of different strategies in after-care for patients who have attempted suicide. Journal of the Royal Society of Medicine. 1989; 82: 643-647.

5. Hawton K., Blackstock E. General practice aspects of selfpoisoning and self-injury. Psychological Medicine. 1976; 6: 571-575.

6. Treolar A.J., Pinfold T.J. Deliberate self-harm: An assessment of patients' attitudes to the care they receive. Crisis. 1993; 14: 83-89.

7. Robins E. et al. Some clinical considerations in the prevention of suicide based on a study of 134 successful suicides. American Journal of Public Health and the Nations Health. 1959; 49 (7): 888-899.

8. Conwell Y. Relationships of age and axis I diagnoses in victims of completed suicide: a psychological autopsy study. American Journal of Psychiatry. 1996; 153: 1001-1008.

9. Harris E.C., Barraclough B. Suicide as an outcome for mental disorders. A meta-analysis. British Journal of Psychiatry. 1997; 170 (3): 205-228.

10. Borges G. et al., Twelve-month prevalence of and risk factors for suicide attempts in the World Health Organization World Mental Health Surveys. J Clin Psychiatry. 2010; 71 (12): 161728.

11. Bertolote J.M. et al., Suicide and mental disorders: do we know enough? Br J Psychiatry 2003; 183: 382-383.

12. De Leo D. Why are we not getting any closer to preventing suicide? British Journal of Psychiatry. 2002; 181: 372-374.

13. Van Praag H.M. A stubborn behaviour: the failure of antidepressants to reduce suicide rates. World J Biol Psychiatry. 2003; 4 (4): 184-191.

14. De Leo D. Suicide prevention is far more than a psychiatric business. World Psychiatry. 2004; 3 (3): 155-156.

15. Hjelmeland H., Knizek B.L. Why we need qualitative research in suicidology. Suicide Life Threat Behav. 2010; 40 (1): 74-80.

16. Rudd M.D., Joiner T., Rajab M.H. Treating suicidal behavior: An effective, time-limited approach. New York: Guilford Press, 2001.

17. Hepp U. et al., Psychological and psychosocial interventions after attempted suicide: an overview of treatment studies. Crisis. 2004; 25 (3): 108-117.

18. Inagaki M. et al., Interventions to prevent repeat suicidal behavior in patients admitted to an emergency department for a suicide attempt: A meta-analysis. Journal of Affective Disorders. 2015; 175: 66-78.

19. Schechter M., Goldblatt M. Validation, Empathy, and Genuine Relatedness, in Building a Therapeutic Alliance with the Suicidal Patient, K. Michel and D.A. Jobes, Editors. American Psychological Association APA Books: Washington, DC, 2011. P. 93-107.

20. Beck A.T. et al. Cognitive therapy of depression. New York: Guilford, 1979.

21. Rudd M.D., Brown G. In Building a Therapeutic Alliance with the Suicidal Patient., K. Michel and D. Jobes, Editors. American Psychological Association, APA Books.: Washington, DC, 2010.

22. Brown G.K., Wenzel A., Rudd M.D. Engaging the Suicidal Patient in Cognitive Therapy, in Building a Therapeutic Alliance with the Suicidal Patient K. Michel and D.A. Jobes, Editors. American Psychological Association APA Books: Washington, DC, 2011. P. 273-291.

23. Rudd M.D., Cukrowicz K.C., Bryan C.J. Core competencies in suicide risk assessment and management: Implications for supervision. Training and Education in Professional Psychology. 2008; 2 (4): 219.
24. Linehan M.M. Skills training manual for treating borderline personality disorder. New York: Guilford Press, 1993.

25. Rizvi S. The Therapeutic Relationship in Dialectical Behaviour Therapy, in Building a Therapeutic Alliance with the Suicidal Patient K. Michel and D.A. Jobes, Editors. American Psychological Association APA Books: Washington, DC, 2011. P. 255-271.

26. Linehan M.M. Validation and psychotherapy, in Empathy Reconsideration: New Directions in Psychotherapy, A.C. Bohart and L. Greenberg, Editors. American Psychological Association: Washington, DC, 1997. P. 353-392.

27. Jobes D.A. Suicidal Patients, the Therapeutic Alliance, and the Collaborative Assessment and Management of Suicidality, in Building a Therapeutic Alliance with the Suicidal Patient K. Michel and D.A. Jobes, Editors. American Psychological Association APA Books: Washington, DC, 2011. P. 205-229.

28. Jobes D.A. et al. A Randomized Controlled Trial of the Collaborative Assessment and Management of Suicidality versus Enhanced Care as Usual With Suicidal Soldiers. Psychiatry. 2017; 80 (4): 339-356.

29. Gollwitzer P.M. The volitional benefits of planning, in The psychology of action. Linking cognition and motivation to behavior, P.M. Gollwitzer and J.A. Bargh, Editors. The Guilford Press: New York, 1996.

30. von Cranach M., Valach L. Action theory in The dictionary of personality and social psychology R.L.R. Harré, Editor. Blackwell Reference: Oxford, 1986. P. 2-4.

31. Carver C.S., Scheier M. Principles of self-regulation: Action and emotion, in Handbook of motivation and cognition: Foundations of social behavior, E.T. Higgins and R.M. Sorrentino, Editors. Guilford Press: New York, 1990. P. 3-52.

32. Michel K., Valach L. Suicide as goal-directed action. Archives of Suicide Research. 1997; 3 (3): 213-221.

33. Baumeister R.F. Suicide as escape from self. Psychological Review. 1990; 97 (1): 90-113.

34. Holmes J. Attachment Theory and the Suicidal Patient, in Building a Therapeutic Alliance with the Suicidal Patient K. Michel and D.A. Jobes, Editors. American Psychological Association APA Books: Washington, DC, 2011. P. 149-168.

35. Adler H.M. The history of the present illness as treatment: who's listening, and why does it matter? The Journal of the American Board of Family Practice. 1997: 10 (1): 28-35.

36. Michel K. et al. Discovering the truth in attempted suicide. American Journal of Psychotherapy. 2002; 56 (3): 424-437.

37. Horvath A.O., Symonds B.D. Relation between working alliance and outcome in psychotherapy: A meta-analysis. Journal of Counseling Psychology. 1991; 38 (2): 139-149.

38. Saltzman C. et al. Formation of a therapeutic relationship: Experiences during the initial phase of psychotherapy as predictors of treatment duration and outcome. Journal of Consulting and Clinical Psychology. 1976; 44 (4): 546-555.

39. Zuroff D.C. et al. Relation of therapeutic alliance and perfectionism to outcome in brief outpatient treatment of depression. Journal of Consulting and Clinical Psychology. 2000; 68 (1): 114.

40. Alexander L.B., Luborsky L. The Penn Helping Alliance Scales, in The Psychotherapeutic Process: A Research Handbook, L.S. Greenberg and W.M. Pinsoff, Editors. Guilford Press: New York, 1986. P. 325-366.

41. Michel K. et al. Therapist sensitivity towards emotional lifecareer issues and the working alliance with suicide attempters. Archives of Suicide Research. 2004; 8 (3): 203-213.

42. Hermans H.J.M., Hermans-Jansen E. Self-narratives: the construction of meaning in psychotherapy. New York: Guilford Press, 1995.

43. Young R.A. et al. Career research from an action perspective: The self-confrontation procedure. Career Development Quarterly. 1994; 43: 185-196. 
44. Valach L. et al. Self-confrontation interview with suicide attempters. 2002.

45. Michel K., Gysin-Maillart A. ASSIP - Attempted Suicide Short Intervention Program. A manual for clinicians. 2015, Göttingen: Hogrefe Publishing.

46. Gysin-Maillart A. et al. A Novel Brief Therapy for Patients Who Attempt Suicide: A 24-months Follow-Up Randomized Controlled Study of the Attempted Suicide Short Intervention Program (ASSIP). PLoS Med. 2016; 13 (3): e1001968.

47. Gysin-Maillart A.C. et al. Suicide Ideation Is Related to Therapeutic Alliance in a Brief Therapy for Attempted Suicide. Arch Suicide Res. 2017; 21 (1): 113-126.

48. Ring M., Gysin-Maillart A. Patients' Satisfaction With the Therapeutic Relationship and Therapeutic Outcome Is Related to Suicidal Ideation in the Attempted Suicide Short Intervention Program (ASSIP). Crisis. 2020; 4: 1-7.

49. Park A.L. et al. Cost-effectiveness of a Brief Structured Intervention Program Aimed at Preventing Repeat Suicide Attempts Among Those Who Previously Attempted Suicide: A Secondary Analysis of the ASSIP Randomized Clinical Trial. JAMA Netw Open. 2018; 1 (6): e183680.

50. Bowlby J. A secure base. Clinical applications of attachment theory. London: Routledge, 1988.
51. Holmes J. The search for the secure base : attachment theory and psychotherapy. Hove, East Sussex; Philadelphia, PA: Brunner-Routledge. xiv, 2001. 183 p.

52. Allen J.G., Fonagy P., Bateman A., Mentalizing in clinical practice. Washington, DC: American Psychiatric Publishing, 2008.

53. Colom F. Keeping therapies simple: psychoeducation in the prevention of relapse in affective disorders. British Journal of Psychiatry. 2011; 198 (5): 198-338.

54. Motto J.A., Bostrom A.G. Empirical indicators of near-term suicide risk. Crisis: The Journal of Crisis Intervention and Suicide Prevention, 1990.

55. Carter G.L. et al. Postcards from the EDge: 5-year outcomes of a randomised controlled trial for hospital-treated self-poisoning. British Journal of Psychiatry. 2013; 202 (5): 372-380.

56. Ryan R.M., Deci E.L. Self-determination theory and the facilitation of intrinsic motivation, social development, and well-being. Am Psychol. 2000; 55 (1): 68-78.

\section{PEOPLE WHO ATTEMPT SUICIDE NEED A SPECIFIC THERAPY}

\section{K. Michel}

University of Bern, Switzerland; konrad.michel@upd.unibe.ch

\section{Abstract:}

Attempted suicide is the main risk factor for repeated suicide attempts and death by suicide. So far there have only been very few therapy programs that have been successful in effectively reducing the suicide risk for suicide attempters. This article argues that the traditional medical model of suicide is not helpful for active treatment engagement of the patients, and that we need a different approach to the suicidal patient. Our research team developed and evaluated a novel, brief and very cost-effective therapy program (the Attempted Suicide Short Intervention Program ASSIP). In contrast to the medical model, which conceptualizes suicide as a consequence of a psychiatric illness, the ASSIP model is based on the concept of suicide as a personal action, which can be understood in a collaborative therapeutic approach. The action-theoretical approach is radically patient-centred, in that the patients are seen as the agents of their suicide actions. This approach fosters the patients' active engagement in therapy. A central element is the patient's self-narrative, which puts the suicide attempt in a biographical context. With the help of the therapist, the suicidal crisis can be understood, explained, and revised. ASSIP has been evaluated in a randomized controlled trial with 120 participants. At 24 months follow-up, the treatment group had a remarkable $80 \%$ reduced risk of reattempting suicide. The article explains the theoretical background and the development of ASSIP, followed by a summary of the ASSIP sessions and a discussion of the therapy process factors.

Keywords: attempted suicide, suicide prevention, psychotherapy, therapeutic alliance, randomized controlled trial

Финансирование: Исследование не имемо финансовой поддержки.

Financing: The study was performed without external funding.

Конфиикт интересов: Автор заявцяет об отсутствии конфиикта интересов.

Conflict of interest: The author declares no conflict of interest.

Статья поступима / Article received: 29.03.2020. Принята к публикации / Accepted for publication: 09.06.2020.

Для цитирования: $\quad$ Michel K. Людям, совершившим попытку самоубийства, нужна особая психотерапия. Суицидология. 2020; 11 (2): 51-65. doi.org/10.32878/suiciderus.20-11-02(39)-51-65

For citation: $\quad$ Michel K. People who attempt suicide need a specific therapy. Suicidology. 2020; 11 (2): 51-65. (In Russ) doi.org/10.32878/suiciderus.20-11-02(39)-51-65 